\title{
Assessment of Respiratory Symptoms among Woodworkers in Jimma Town, Southwest Ethiopia, A Comparative Cross-Sectional Study
}

\author{
Dilnessa Fentie ${ }^{1}$, Tewodros G/Mariam², Elias Mulat ${ }^{2}$ and Wondu Reta*2 \\ ${ }^{1}$ Department of Biomedical Sciences, College of public health, Dire Dewa University, Dire Dewa, Ethiopia \\ ${ }^{2}$ Department of Biomedical Sciences, School of Medicine, Institute of Health, Jimma University, Jimma, Ethiopia \\ *Corresponding author: Wondu Reta Demissie, Jimma University, Institute of Health, School of Medicine, Department of \\ Biomedical sciences, Jimma, Ethiopia
}

\section{ARTICLE INFO}

Received: 幽 May 14, 2019

Published: May 23, 2019

Citation: Dilnessa Fentie, Tewodros G/Mariam, Elias Mulat, Wondu Reta. Assessment of Respiratory Symptoms among Woodworkers in Jimma Town, Southwest Ethiopia, A Comparative Cross-Sectional Study. Biomed J Sci \& Tech Res 18(2)-2019. BJSTR. MS.ID.003125.

Keywords: Respiratory Symptoms; Woodworkers; Jimma Town; Comparative Cross-Sectional

\begin{abstract}
Background: Wood dust is one of the most common sources of occupational exposures in the world.

Objective: The aim of the present study was to assess respiratory symptoms among woodworkers of Jimma town, Ethiopia, 2018 G.C.

Materials and Method: A community based comparative cross-sectional study was conducted among woodworkers and non-woodworkers in Jimma town, 2018 G.C. Multistage random sampling technique was used to select the exposed study group and convenience sampling technique was used to select the non-exposed group. A standardized structured questionnaire was used to evaluate the respiratory symptoms. A total of 140 study participants were enrolled in the study. Data were checked for completeness, entered into Epi data version 1.7 and exported to SPSS version 20 for further analysis. Descriptive statistics were computed, and results were presented with narratives, tables or figures.
\end{abstract}

Results: Higher prevalence of respiratory symptoms was observed among woodworkers than non-woodworkers. The prevalence of respiratory symptoms like cough ( $41.4 \%$ vs. $10 \%$ ), phlegm ( $34.3 \%$ vs. $14.3 \%$ ) and chest pain (32.9 vs. 17.1) shows statistically significance differences among exposed to non-exposed groups respectively

Conclusion and Recommendation: The higher prevalence of respiratory symptoms among woodworkers needs due emphasis on preventive measures and awareness creation about wood dust-related respiratory symptoms.

\section{Introduction}

Jimma is one of the oldest cities of Ethiopia, known as the ever green, forestry, 13 month of raining, coffee land and endemic with wood and wood products [1]. Many scholars also argue that Jimma was claimed as the home of respiratory disorders especially asthma [2]. The present study hypothesis that the unique and endemic of the town with wood and wood products exposes woodworkers to different respiratory disorders which manifested with respiratory sign and symptoms as occupational hazard. Exposure to wood dust is responsible for development of varies respiratory diseases as occupation hazard and affecting about two million workers worldwide [3-6]. Dusts from the wood and its different components enters into respiratory systems via inhalation to cause respiratory disorders by sensitizing and irritating mucous membrane of airways which are manifested by different sign and symptoms among exposed wood workers [7-14]. A meta- analysis study conducted in Great Britain has shown exposure to woodwork was associated with significantly increased risk of respiratory symptoms and asthma among furniture and wood processing [15].

The other study conducted in Asian countries revealed that wood dust is more prone to cause irritant respiratory symptoms 
and a potent cause of chronic respiratory diseases among wood workers [9]. Despite there is no study conducted on the interested area in the setting and as well as in the country, there are different studies conducted among woodworkers to evaluate the magnitude of respiratory symptoms globally [3,5,8,11-14,16-36]. Previous study conducted in the setting among woodworkers reported higher magnitude of respiratory disorders than the control group [37] and also study done among cobblestone road paving workers revealed the significant higher odds of respiratory symptoms, (dry cough $(\mathrm{p}<0.05)$, cough $(\mathrm{p}<0.01)$ and sore throat $(\mathrm{p}<0.001))$ compared to the reference group [38]. Study conducted among street sweepers in Addis Ababa showed the high prevalence respiratory symptoms [39]. Thus, the present study was aimed to assess respiratory symptoms among wood workers in Jimma town by taking reference group.

\section{Materials and Methods}

\section{Study Area and Period}

The study was conducted in Jimma town, located in the Oromia region, about $354 \mathrm{~km}$ distance to southwest direction, from the capital city of the country and Oromia, Finfinne. The town has 17 kebeles with a total population of 159,009 of whom 80,897 were males. The town has an altitude of 1750-2000 m above sea level with a temperature range of $20-30^{\circ} \mathrm{C}$ and average annual rainfall of $800-2500 \mathrm{~mm}^{3}$. According to Jimma town entrepreneur and food security agency of 2017/2018 report, there are 300 small-scale wood processing industries in the town involving 1012 male and 548 female woodworkers. The data was collected from April 5 to May 3, 2018 G.C among sampled wood workers and non-exposed group (shopkeepers) for comparison by employing comparative cross-sectional study design.

\section{Selection Criteria}

The woodworkers as exposed group with one year and above experience and non-exposed group (shopkeepers) who had never worked in woodwork or other wood related industry were recruited in matching with year of service, age, sex and BMI. All individuals of both groups (exposed and non-exposed) with history of pulmonary tuberculosis, heart failure, common cold, history of smoking, any acute illness was excluded from the study.

\section{Sample Size Determination}

The sample size was determined by using analytical study sample size calculation formula by taking two-sided confidence level of $95 \%$, a power of $80 \%$ with a double proportion formula.

$$
n=\left[\frac{r+1}{r}\right] \frac{p \times q\left(Z_{\beta}+Z_{\alpha}\right)^{2}}{d^{2}}
$$

Where: $\mathrm{n}$ = sample size required in each group

$\mathrm{Z} \mathrm{a} / 2$ = critical value at 95\% confidence level of certainty (1.96) (a constant).

Zß: This depends on power, (the probability that if the two proportions differ the test will produce a significant difference) for $80 \%$ this is 84

P1=Prevalence of symptoms among exposed group/cases

P2= Prevalence of symptoms among non -exposed controls

$p=$ average percentage between two groups $=(p 1+p 2) / 2$

$\mathrm{q}=1-\mathrm{p}$

$\mathrm{d}=$ clinically meaningful difference between two groups (p1p2)

$r=$ ratio of exposed to non-exposed $=1$ because of equal number of exposed to non-exposed group.

Based on the previous study conducted in Cameroon by Francis NDE et al with the magnitude of respiratory symptoms among woodworkers (cough $34.5 \%$ among exposed group and $6.6 \%$ among non- exposed group) was used for sample calculation [16].

$\mathrm{n}($ each group $)=[(2) \times(.21) \times(.79) \times(1.96+.84) 2] /(.345-.066) 2=$ $33.4 * 2$ (two groups) 67 . Due to multi -stage sampling technique the calculated sample size was multiplied by 2 (design effect) which equals to 134 . By adding $5 \%$ of the non- response rate the total sample size was 140 for both exposed and non-exposed groups.

\section{Sampling Technique}

Multistage sampling technique was used to select the exposed study participants. First, five kebeles were selected by simple random sampling from the total 17 kebeles of the town. Then, by considering equal weight allocation of the sample to each selected kebeles; 14 small-scale wood work enterprises were selected by simple random sampling from the total 300 small-scale wood processing industries distributed in kebeles of the town. From each enterprise, one eligible respondent was selected by simple random sampling method. The comparison group of shopkeepers was selected by convenience sampling technique matching with age, sex, duration of service and body mass index to sampled woodworkers. (Figure 1). 


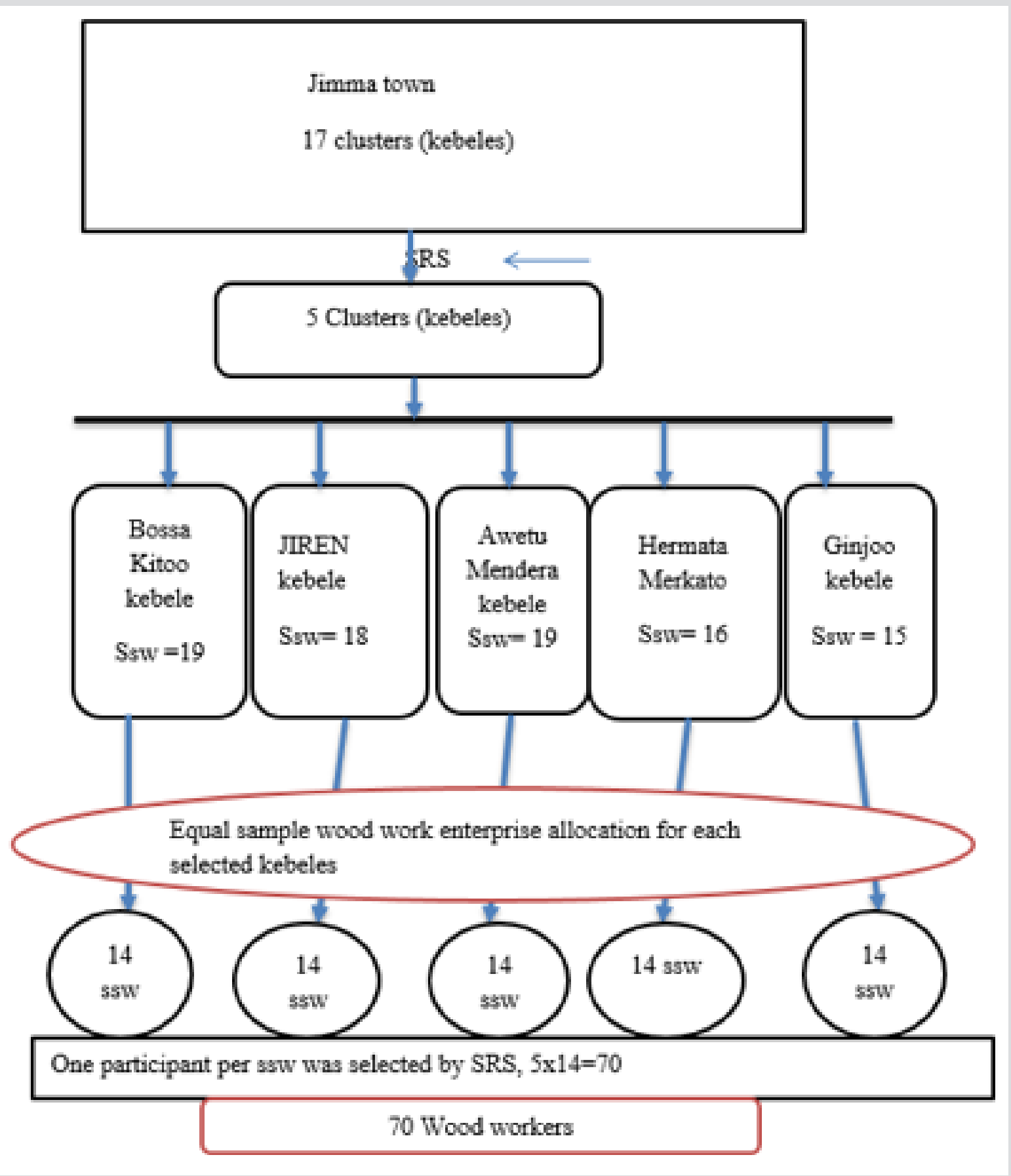

Figure 1: Schematic presentation of sampling procedure conducted to select study participants among woodworkers in Jimma town, southwest Ethiopia 2018 G.C.

(Source: Jimma town Entrepreneur \& food security Agency, 2017/2018).

SRS=Simple Random Sampling, SSW=small scale woodwork industry

\section{Data Analysis}

Data was checked for completeness, entered into Epi-data version 1.7 and finally exported to SPSS version 20 for further analysis. Descriptive statistics were used to summarize the finding. Statistical analysis of the difference between proportions was done by the use of the chi-square test.

\section{Ethical Consideration}

Ethical clearance was obtained from the Institutional Review Board (IRB) of Jimma University, Institute of Health with specific number of $260 / 2018$. Letter of cooperation was obtained from Jimma university postgraduate school to facilitate study. Oral and Written consent was obtained from participants before data 
collection. The objectives of the study were explained to each study participants. The information obtained in the study participants was handled confidentially and not disclose to third party.

\section{Result}

\section{Socio- Demographic Characteristics}

A total of 140 (70 woodworkers and 70 shopkeepers) were recruited in the study. The mean age of woodworkers and non- woodworkers were 27.86 (SD \pm 7.88 ) years and 26.49 years (SD \pm 5.378 ) respectively. The mean height and weight of woodworkers and non-woodworkers were $169.90 \mathrm{~cm}(\mathrm{SD} \pm$ 6.084) vs 170.66 $\mathrm{cm}(\mathrm{SD} \pm 5.941)$ and $59.89 \mathrm{Kg}(\mathrm{SD} \pm 5.77)$ vs $59.99 \mathrm{Kg}(\mathrm{SD} \pm 5.59)$ respectively. The mean service year duration of woodworkers and non-woodworkers was $7.20 \pm 5.45$ and $7.45 \pm 4.40$ respectively with range between 1 to 22 years in both groups (Table 1 ).

Table 1: Socio -demographic characteristics of woodworkers and reference population in Jimma town, Southwest Ethiopia, 2018 G.C.

\begin{tabular}{|c|c|c|c|}
\hline Parameter & Woodworkers (n=70) & Non-Woodworkers (N=70) & P-value \\
\hline Age, mean \pm SD & $27.86 \pm 7.886$ & $26.49 \pm 5.378$ & 0.209 \\
\hline Height, mean \pm SD & $169.74 \pm 5.93$ & $170.80 \pm 5.958$ & 0.95 \\
\hline Weight, mean \pm SD & $59.89 \pm 5.77$ & $59.99 \pm 5.599$ & 0.917 \\
\hline BMI, mean \pm SD & $20.7871 \pm 1.70$ & $20.548 \pm 1.22$ & 0.344 \\
\hline $\begin{array}{c}\text { Level of education: } \\
\text { Primary, number (\%) }\end{array}$ & $24(34.3 \%)$ & $20(28.6 \%)$ & 0.453 \\
\hline Secondary, number (\%) & $30(42.9 \%)$ & $30(42.9 \%)$ & 0.568 \\
\hline Higher, number (\%) & $10(14.3 \%)$ & $18(25.7 \%)$ & 0.465 \\
\hline Others, number (\%) & $6(7.21 \%)$ & $2(2.9 \%)$ & 0.54 \\
\hline Duration of service, mean \pm SD & $7.20 \pm 5.45$ & $7.45 \pm 4.40$ & $0.04 *$ \\
\hline
\end{tabular}

$\mathrm{P}<.05$ significant, BMI- body mass index, SD-standard deviation

*-Significant p-value for prevalence of respiratory Symptoms

\section{Prevalence of Respiratory Symptoms}

The prevalence of the respiratory symptoms in the last 12 months was higher among woodworkers when compared to nonwoodworkers. The prevalence of dry cough, cough with phlegm expectoration, chest pain, breathlessness, and wheeze with $95 \%$ confidence interval were $41.4 \%$ (31.4 - 51.7), 34.3\% (25.5 - 48.6), $32.9 \%$ (22.6 - 47.1), 21.4\% (9.7 - 29.1), and $12.9 \%$ (5.2 - 22.9) for exposed study participants respectively and the prevalence of phlegm expectoration, dry cough, chest pain, breathlessness, and wheeze for non- exposed group with 95\% confidence interval were $14.3 \%$ (5.7 - 23.1), 10\% (2.6 - 17.4), 17.1\% (10 - 28.2), $14.3 \%$ (5.7 - 23.7) and 8.6\% (3.5 - 17.1) respectively. Moreover, all respiratory symptoms except breathlessness and wheezing showed statistically significant differences between woodworkers and non-woodworkers. Woodworkers were 6.36 times more likely to develop dry cough, 2.94 times more likely to phlegm production, 2.36 times more likely to have chest pain, 1.64 more likely to develop breathlessness and 1.57 times more likely to develop wheezing than non-woodworkers.(Table 2).

Table 2: The prevalence of respiratory symptoms in the last 12 months in woodworkers and non-woodworkers in Jimma town, Southwest Ethiopia, 2018.

\begin{tabular}{|c|c|c|c|c|c|c|c|}
\hline \multirow{2}{*}{$\begin{array}{c}\text { Respiratory Symptoms in the } \\
\text { Last 12 Months }\end{array}$} & \multirow{2}{*}{$\begin{array}{c}\text { Woodworkers } \\
\mathbf{n = 7 0}\end{array}$} & \multicolumn{2}{|c|}{$\mathbf{9 5 \% C I}$} & \multirow{2}{*}{$\begin{array}{c}\text { Non-Woodworkers } \\
\mathbf{n = 7 0}\end{array}$} & \multicolumn{2}{|c|}{$\mathbf{9 5 \% C I}$} & \multicolumn{2}{|c|}{ P-value } \\
\cline { 3 - 4 } & Lower & Upper & Lower & Upper & \\
\hline Cough & $29(41.4 \%)$ & 31.4 & 51.7 & $7(10 \%)$ & 2.6 & 17.4 & $0.000^{* *}$ \\
\hline Phlegm Expectoration & $24(34.3 \%)$ & 25.5 & 48.6 & $10(14.3 \%)$ & 5.7 & 23.1 & $0.010^{*}$ \\
\hline Breathleness & $15(21.5 \%)$ & 9.7 & 29.1 & $10(14.3 \%)$ & 5.7 & 23.7 & $0.412^{*}$ \\
\hline Wheezing & $9(12.4 \%)$ & 5.2 & 22.9 & $6(8.6 \%)$ & 3.5 & 17.1 & $0.270^{*}$ \\
\hline Chest pain & $23(32.9 \%)$ & 22.6 & 47.1 & $12(17.1 \%)$ & 10 & 28.2 & $0.032^{*}$ \\
\hline
\end{tabular}

Statically significant $(\mathrm{p}<.05),{ }^{* *} \mathrm{p}<.0001$

*Tested by chi-square test

\section{Discussion}

The finding of the present study revealed that exposure of wood dust among the woodworkers resulted in higher prevalence of respiratory symptoms compared to non-woodworkers. There is statistically significant difference discriminated among the groups in cough (41.4\% vs. 10\%), phlegm expectoration $(34.3 \%$ vs.14.3\%), chest pain (32.9\% vs. $17.1 \%)$. But the prevalence of 
breathlessness and wheeze among woodworkers were higher than non-woodworkers but didn't reach statistical significant difference between groups. The higher prevalence of respiratory symptoms among woodworkers could be air pollution in the working environment due to wood dust resulting in activation and infiltration of inflammatory cells ( $\mathrm{T}$ cells, mast cells, basophils, eosinophil's, neutrophils, and/or macrophages) in the respiratory system and allergic sensitization that could facilitate the development of allergic alveolitis, hyper-responsiveness of the air ways, irritation of cough receptors, hypertrophy of smooth muscle cells due to recurrent hyper-responsive bronchial constriction and hyperplasia of goblet cells that leads to development different respiratory symptoms [41-43].

The present finding was comparable to study done by Francis NDE et al who revealed higher prevalence of respiratory symptom among woodworkers than non-woodworkers with magnitude of dry cough $34.5 \%$ vs. $6.6 \%$ and phlegm expectoration $3.1 \%$ vs. $0.8 \%$ respectively with statistically significant difference [16]. Another study conducted in Republic of Macedonia by Dragana Bislimovska et al also supported the present finding as reported higher prevalence of respiratory symptoms among woodworkers than non-woodworkers with magnitude of cough $(29.7 \%$ vs. $13.5 \%)$, phlegm (15.2\% vs. $5.4 \%$ ), shortness of breath (10.8\% vs. $8.1 \%)$, chest pain (13.5\% vs. $10.8 \%$ ) respectively [26]. The present study was also in harmony with study of Tobin EA et al who reported the higher prevalence of respiratory symptoms among the exposed study group [cough $46.7 \%$, phlegm expectoration $50.2 \%$, wheeze $5.3 \%$, chest tightness $10.1 \%$, chest pain $5.7 \%$ and breathlessness $7.5 \%$ ] than the comparison group [24]. The present finding was also in agreement with results of other studies [25,36,44,45].

\section{Study Limitation}

The respiratory symptoms were assessed based on study participant health history; so, it might be prone to recall bias. This study didn't measure concentration of dust between woodwork and shopkeepers working environment. The present study didn't include both sexes because of unavailability of female woodworkers.

\section{Conclusion}

The prevalence of respiratory symptoms among wood workers was higher than non-woodworkers. Moreover, all respiratory symptoms except breathlessness and wheezing showed statistically significant differences between woodworkers and nonwoodworkers.

\section{Acknowledgement}

We would like to thank Jimma University for financial support and participants of the study.

\section{References}

1. (2019) Jimma. Wikipedia.
2. Tefereedgn EY, Ayana AM, Tefereedgn EY, Ayana AM (2018) Prevalence of Asthma and Its Association with Daily Habits in Jimma Town, Ethiopia. Open J Asthma 2(1): 11-17.

3. Schlünssen V, Schaumburg I (1998) Asthma, bronchitis and chronic obstructive pulmonary disease in occupational exposure to wood. Ugeskr Laeger 160(5): 609-615.

4. Baran S, Swietlik K, Teul I (2009) Lung function: occupational exposure to wood dust. Eur J Med Res 14(Supply4): 14

5. Jacobsen G, Schaumburg I, Sigsgaard T, Schlunssen V (2010) Nonmalignant respiratory diseases and occupational exposure to wood dust. Part II. Dry wood industry. Ann Agric Environ Med 17(1): 29-44.

6. Carton M, Goldberg M, Luce D (2002) Occupational exposure to wood dust. Health effects and exposure limit values. Rev Epidemiol Sante Publique 50(2): 159-178.

7. Esmaeil N, Gharagozloo M, Rezaei A, Grunig G (2014) Dust events, pulmonary diseases and immune system. Am J Clin Exp Immunol 3(1): 20-29.

8. Shamssain MH (1992) Pulmonary function and symptoms in workers exposed to wood dust. Thorax 47(2): 84-87.

9. Ratnasingam J, Ioras F, Tadin I, Wai LT, Ramasamy G (2014) Respiratory Effects in Woodworkers Exposed to Wood and Wood Coatings Dust: A Regional Evaluation of South East Asian Countries. J Appl Sci 14(15): 1763-1768.

10. Holmström M, Wilhelmsson BO (1988) Respiratory symptoms and pathophysiological effects of occupational exposure to formaldehyde and wood dust. Scand J Work Environ Health 14(5): 306-311.

11. Lion SH, Yang JL, Cheng SY, Lai FM (1996) Respiratory symptoms and pulmonary function among wood dust-exposed joss stick workers. Int Arch Occup Environ Health 68(3): 154-160.

12. Goldsmith DF, Shy CM (1988) Respiratory health effects from occupational exposure to wood dusts. Scand J Work Environ Health 14(1): 1-15.

13. Schlünssen V, Schaumburg I, Taudorf E, Mikkelsen AB, Sigsgaard T (2002) Respiratory symptoms and lung function among Danish woodworkers. J Occup Environ Med 44(1): 82-98.

14. Rastogi SK, Gupta BN, Husain T, Mathur N (1989) Respiratory Health Effect from Occupational Exposure to Wood Dust in Sawmills. Am Ind Hyg Assoc J 50(11): 574-578.

15. Wiggans RE, Evans G, Fishwick D, Barber CM (2016) Asthma in furniture and wood processing workers: a systematic review. Occup Med 66(3): 193-201.

16. Nde Djiele J, Mbatchou H, Nebo J, Djomo A, Tsafack P, et al. (2015) Respiratory symptoms and pulmonary function tests among informal sectors workers exposed to wood dust in Douala, Cameroon. J Allergy Ther 6: 6 .

17. Kayhan S, Tutar U, Cinarka H, Gumus A, Koksal N (2013) Prevalence of occupational asthma and respiratory symptoms in foundry workers. Pulm Med 2013: 1-4.

18. Löfstedt H akan, Hagström K, Bryngelsson IL, Holmström M, Rask Andersen A (2017) Respiratory symptoms and lung function in relation to wood dust and monoterpene exposure in the wood pellet industry. Ups J Med Sci 122(2): 78-84.

19. Bohadana AB, Massin N, Wild P, Toamain J-P, Engel S, Goutet P (2000) Symptoms, airway responsiveness, and exposure to dust in beech and oak wood workers. Occup Environ Med 57(4): 268-273.

20. Campo P, Aranda A, Rondon C, Doña I, Díaz Perales A, et al. (2010) Workrelated sensitization and respiratory symptoms in carpentry apprentices exposed to wood dust and diisocyanates. Ann Allergy Asthma Immunol 105(1): 24-30. 
21. Mandryk J, Alwis KU, Hocking AD (1999) Work-related symptoms and dose-response relationships for personal exposures and pulmonary function among woodworkers. Am J Ind Med 35(5): 481-490.

22. Milanowski J, Krysińska Traczyk E, Skorska G, Cholewa G, Sitkowska J, et al. (1996) The effect of wood dust on the respiratory system. Medical examination of furniture factory workers. Pneumonol Alergol Pol 64(Supply1): 32-37.

23. Mahmood NMA, Karadaky K, Hussain SA, Ali AK, Mohammad GM, et al. (2016) Respiratory function among sawmill workers in different areas of Sulaimani city. Int J Med Sci \& Pub Health 5(2): 351.

24. Tobin EA, Ediagbonya TF, Okojie OH, Asogun DA (2016) Occupational Exposure to Wood Dust and Respiratory Health Status of Sawmill Workers in South-south Nigeria. J Pollut Eff Control 4: 154.

25. Boskabady MH, Rezaiyan MK, Navabi I, Shafiei S, Arab SS (2010) Workrelated respiratory symptoms and pulmonary function tests in northeast iranian (the city of Mashhad) carpenters. Clinics 65(10): 1003-1007.

26. Bislimovska D, Petrovska S, Minov J (2015) Respiratory symptoms and lung function in never-smoking male workers exposed to hardwood dust. Open Access Maced J Med Sci 3(3): 500-505.

27. Asia AA, Atram GG (2017) Respiratory symptoms and ventilatory functions among sawmill workers. Indian Journal of Basic and Applied Medical Research 6(4): 336-340.

28. Borm PJA, Jetten M, Hidayat S, Van de Burgh N, Leunissen P, et al. (2002) Respiratory symptoms, lung function, and nasal cellularity in Indonesian wood workers: a dose-response analysis. Occup Environ Med 59(5): 338-344.

29. Jacobsen G, Schlünssen V, Schaumburg I, Sigsgaard T (2009) Increased incidence of respiratory symptoms among female woodworkers exposed to dry wood. Eur Respir J 33(6): 1268-1276.

30. Liou SH, Cheng SY, Lai FM, Yang JL (1996) Respiratory symptoms and pulmonary function in mill workers exposed to wood dust. Am J Ind Med 30(3): 293-299.

31. Wilhelmsson B, Drettner B (1984) Nasal problems in wood furniture workers: A study of symptoms and physiological variables. Acta Otolaryngol (Stockh) 98(5-6): 548-555.

32. Mandryk J, Alwis KU, Hocking AD (2000) Effects of personal exposures on pulmonary function and work-related symptoms among sawmill workers. Ann Occup Hyg 44(4): 281-289.

33. Osman E, Pala K (2009) Occupational exposure to wood dust and health effects on the respiratory system in a minor industrial estate in Bursa/ Turkey. Int J Occup Med Environ Health 22(1): 43-50.

\section{ISSN: 2574-1241}

\section{DOI: 10.26717/BJSTR.2019.18.003125}

Wondu Reta Demissie. Biomed J Sci \& Tech Res

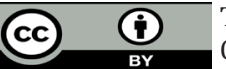

his work is licensed under Creative Commons Attribution 4.0 License

Submission Link: https://biomedres.us/submit-manuscript.php
34. Pisaniello DL, Connell KE, Muriale L (1991) Wood dust exposure during furniture manufacture-results from an Australian survey and considerations for threshold limit value development. Am Ind Hyg Assoc J 52(11): 485-492.

35. Pisaniello DL, Tkaczuk MN, Owen N (1992) Occupational wood dust exposures, lifestyle variables, and respiratory symptoms. J Occup Med 34(8): 788-792.

36. Sripaiboonkij P, Phanprasit W, Jaakkola MS (2009) Respiratory and skin effects of exposure to wood dust from the rubber tree Hevea brasiliensis. Occup Environ Med 66(7): 442-447.

37. Dilnessa Fentie, Tewodros G Mariam, Elias Mulat, Wondu Reta Demissie (2019) Prevalence of Respiratory Disorders among Woodworkers in Jimma Town, Southwest Ethiopia. J Pulm Med Respir Res 5: 22

38. Hassen KA, Ibrahim MS (2014) Exposure to occupational dust and changes in pulmonary function among cobblestone paving workers of Jimma, Ethiopia. Rev Ambiente Água 9(1): 19-26.

39. Abraha MT, Gebremeskel Hidat, Teklehaimanot M, Gebremedhin B (2016) Occupational Respiratory Health Symptoms and Associated Factors among Street Sweepers in Addis Ababa, Ethiopia.

40. Jain S, Gupta A, Jain D (2015) Estimation of sample size in dental research. Int Dent Med J Adv Res 1(1): 1-6.

41. Robalo Cordeiro C, Cemlyn Jones J, Alfaro TM, Ferreira AJ (2007) Bronchoalveolar lavage in occupational lung diseases. Semin Respir Crit Care Med 28(5): 504-513.

42. Määttä J (2008) Cytokine, Chemokine, and Chemokine Receptor Expression in RAW 264.7 Mouse Macrophages and in the Lungs of Mice After Exposure to Wood Dust. University of Kuopio.

43. Pylkkänen L, Stockmann Juvala H, Alenius H, Husgafvel Pursiainen K, Savolainen K (2009) Wood dusts induce the production of reactive oxygen species and caspase- 3 activity in human bronchial epithelial cells. Toxicology 262(3): 265-270.

44. Oppliger A, Rusca S, Charriere N, Vu Duc T, Droz PO (2005) Assessment of bioaerosols and inhalable dust exposure in Swiss sawmills. Ann Occup Hyg 49(5): 385-391.

45. Hailu S, Tessema T, Silverman M (2003) Prevalence of symptoms of asthma and allergies in schoolchildren in Gondar town and its vicinity, northwest Ethiopia. Pediatr Pulmonol 35(6): 427-432.

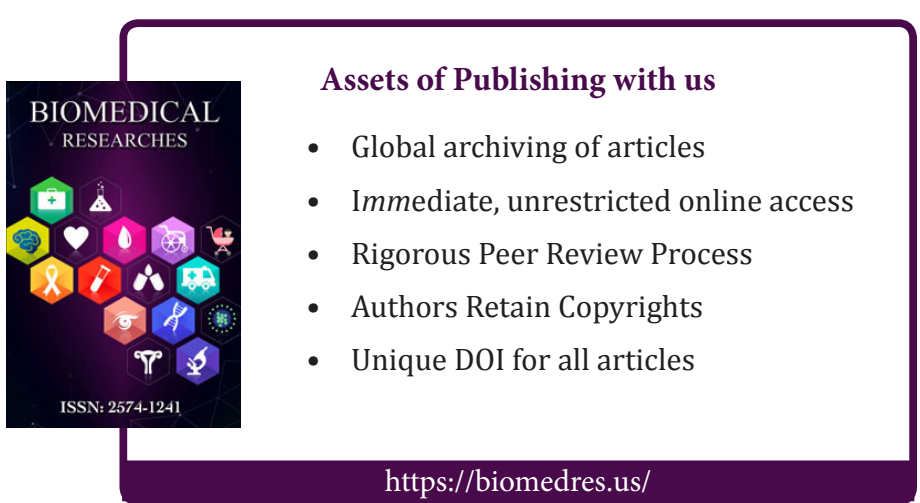

